\title{
PENDEKATAN PENDIDIKAN BERBASIS MUTU
}

\author{
Oleh: Ridwan Idris*
}

\begin{abstract}
It is widely accepted that educational institution plays an important role in developing human resource. Due to this, high quality educational institutions should be thoroughly developed. It is argued that to develope high quality education depends strongly on the government policy, particularly in the issue of autonomy level of the institution. The concept of school based management which leads educational institution to be more independent is a relevant model of developing good quality education. This model allows community at large to actively participate in developing the quality of education.
\end{abstract}

KEYWORDS: Konsep, pendidikan, mutu, manajemen

PERKEMBANGAN ilmu pengetahuan dan teknologi telah membawa perubahan di hampir semua aspek kehidupan manusia. Di era ini berbagai permasalahan hanya dapat dipecahkan dengan upaya penguasaan dan peningkatan ilmu pengetahuan dan teknologi. Selain manfaat bagi kehidupan manusia di satu sisi perubahan tersebut juga telah membawa manusia ke dalam era persaingan global yang semakin ketat.

Agar mampu berperan dalam persaingan global, maka sebagai bangsa kita perlu terus mengembangkan dan meningkatkan kualitas sumber daya manusianya. Oleh karena itu, peningkatan kualitas sumber daya manusia merupakan kenyataan yang harus dilakukan secara terencana, terarah, intensif, efektif dan efisien dalam proses pembangunan, kalau tidak ingin bangsa ini kalah bersaing dalam menjalani era globalisasi tersebut.

Berbicara mengenai kualitas sumber daya manusia, pendidikan memegang peran yang sangat penting dalam proses peningkatan kualitas sumber daya manusia. Peningkatan kualitas pendidikan merupakan suatu proses yang terintegrasi dengan proses peningkatan kualitas sumber daya manusia itu sendiri. Menyadari pentingnya proses peningkatan kualitas

*Peraih Magister Pendidikan dalam bidang manajemen pendidikan dari Universitas Negeri Makassar ini adalah kandidat doktor pada Program Studi Manajemen Pendidikan Universitas Negeri Jakarta. Saat ini ia menjadi dosen tetap Fakultas Tarbiyah dan Keguruan UIN Alauddin Makassar. 
sumber daya manusia, maka pemerintah bersama kalangan swasta samasama telah dan terus berupaya mewujudkan amanat tersebut melalui berbagai usaha pembangunan pendidikan yang lebih berkualitas antara lain melalui pengembangan dan perbaikan kurikulum dan sistem evaluasi, perbaikan sarana pendidikan, pengembangan dan pengadaan materi ajar, serta pelatihan bagi guru dan tenaga kependidikan lainnya. Tetapi pada kenyataannya upaya pemerintah tersebut belum cukup berarti dalam meningkatkan kualitas pendidikan.

Memasuki abad ke-21, isu tentang perbaikan sektor pendidikan di Indonesia mencuat ke permukaan, tidak hanya dalam jalur pendidikan umum, tetapi semua jalur dan jenjang pendidikan, bahkan upaya advokasi untuk jalur pendidikan yang dikelola oleh beberapa departemen teknis, dengan tuntutan social equity sangat kuat yang tidak hanya disuarakan oleh departemen terkait sebagai otoritas pengelola jalur pendidikan tersebut, tetapi juga oleh para praktisi dan pengambil kebijakan dalam pembangunan sektor pembinaan sumber daya manusia, karena semua jenis, jalur dan jenjang pendidikan merupakan unsur-unsur yang memberikan kontribusi terhadap rata-rata hasil pendidikan nasional. Dengan demikian, kelemahan proses dan hasil pendidikan dari sebuah jalur pendidikan akan mempengaruhi indeks keberhasilan pendidikan secara keseluruhan. ${ }^{1}$

Salah satu indikator kekurang berhasilan ini ditunjukkan antara lain dengan NEM siswa untuk berbagai bidang studi pada jenjang SLTP dan SLTA yang tidak memperlihatkan kenaikan yang berarti bahkan boleh dikatakan konstan dari tahun ke tahun, kecuali pada beberapa sekolah dengan jumlah yang relatif sangat kecil. Dengan fakta tersebut, prestasi pendidikan Indonesia tertinggal jauh di bawah negara-negara Asia lainnya, seperti Singapura, Jepang dan Malaysia, baik dalam aspek angka partisipasi pendidikan, maupun rata-rata lamanya setiap anak bersekolah. Bahkan, jika dilihat dari indeks sumber daya manusia, yang salah satu indikatornya adalah sektor pendidikan, posisi Indonesia kian menurun dari tahun ke tahun. ${ }^{2}$

Menurut Umaedi ada dua faktor yang dapat menjelaskan mengapa upaya perbaikan mutu pendidikan selama ini kurang atau tidak berhasil. Pertama strategi pembangunan pendidikan selama ini lebih bersifat input oriented. Strategi yang demikian lebih bersandar kepada asumsi bahwa bilamana semua input pendidikan telah dipenuhi, seperti penyediaan buku-buku (materi ajar) dan alat belajar lainnya, penyediaan sarana pendidikan, pelatihan guru dan tenaga kependidikan lainnya, maka secara otomatis lembaga pendidikan (sekolah) akan dapat menghasilkan output (keluaran) yang bermutu sebagaimana yang diharapkan. 
Kedua, pengelolaan pendidikan selama ini lebih bersifat macrooriented, diatur oleh jajaran birokrasi di tingkat pusat. Akibatnya, banyak faktor yang diproyeksikan di tingkat makro (pusat) tidak terjadi atau tidak berjalan sebagaimana mestinya di tingkat mikro (sekolah). Atau dengan singkat dapat dikatakan bahwa kompleksitasnya cakupan permasalahan pendidikan, seringkali tidak dapat terpikirkan secara utuh dan akurat oleh birokrasi pusat. ${ }^{3}$

Diskusi tersebut memberikan pemahaman kepada kita bahwa pembangunan pendidikan bukan hanya terfokus pada penyediaan faktor input pendidikan tetapi juga harus lebih memperhatikan faktor proses pendidikan. Input pendidikan merupakan hal yang mutlak harus ada dalam batas-batas tertentu tetapi tidak menjadi jaminan dapat secara otomatis meningkatkan mutu pendidikan (school resources are necessary but not sufficient condition to improve student achievement).

Di samping itu, mengingat sekolah sebagai unit pelaksana pendidikan formal terdepan dengan berbagai keragaman potensi anak didik yang memerlukan layanan pendidikan yang beragam, kondisi lingkungan yang berbeda satu dengan lainnya, maka sekolah harus dinamis dan kreatif dalam melaksanakan peranannya untuk mengupayakan peningkatan kualitas/mutu pendidikan. Hal ini akan dapat dilaksanakan jika sekolah dengan berbagai keragamannya itu diberikan kepercayaan untuk mengatur dan mengurus dirinya sendiri sesuai dengan kondisi lingkungan dan kebutuhan anak didiknya. Walaupun demikian, agar mutu tetap terjaga dan agar proses peningkatan mutu tetap terkontrol, maka harus ada standar yang diatur dan disepakati secara secara nasional untuk dijadikan indikator evaluasi keberhasilan peningkatan mutu tersebut (adanya benchmarking).

Dewasa ini banyak upaya peningkatan mutu pendidikan terus dilakukan oleh berbagai pihak. Upaya-upaya tersebut dilandasi suatu kesadaran betapa pentingnya peranan pendidikan dalam pengembangan sumber daya manusia dan pengembangan watak bangsa (Nation Character Building) untuk kemajuan masyarakat dan bangsa. Harkat dan martabat suatu bangsa sangat ditentukan oleh kualitas pendidikannya. Dalam konteks bangsa Indonesia, peningkatan mutu pendidikan merupakan sasaran pembangunan di bidang pendidikan nasional dan merupakan bagian integral dari upaya peningkatan kualitas manusia Indonesia secara menyeluruh. ${ }^{4}$

Pemikiran ini telah mendorong munculnya pendekatan baru, yakni pengelolaan peningkatan mutu pendidikan di masa mendatang harus berbasis sekolah sebagai institusi paling depan dalam kegiatan pendidikan. 
Pendekatan ini, kemudian dikenal dengan manajemen peningkatan mutu pendidikan berbasis sekolah (School Based Quality Management) atau dalam nuansa yang lebih bersifat pembangunan (developmental) disebut School Based Quality Improvement. Selain itu, istilah yang sering didengar dalam meningkatkan mutu pendidikan adalah Manajemen Peningkatan Mutu Berbasis Sekolah (MPMBS) yang menekankan pada peningkatan partisipasi warga sekolah dan penyerahan kewenangan seluas-luasnya kepada sekolah dalam mengambil keputusan dan dalam melaksanakan kegiatannya dan dengan kewenangan dan partisipasi itu sekolah memiliki keleluasaan yang cukup besar dalam mengembangkan sekolahnya yang pada gilirannya dapat meningkatkan mutu sekolah. ${ }^{5}$

Konsep yang menawarkan kerjasama yang erat antara sekolah, masyarakat dan pemerintah dengan tanggung jawabnya masing-masing ini, berkembang didasarkan kepada suatu keinginan pemberian kemandirian kepada sekolah untuk ikut terlibat secara aktif dan dinamis dalam rangka proses peningkatan kualitas pendidikan melalui pengelolaan sumber daya sekolah yang ada.

Dengan pendekatan tersebut sekolah harus mampu menerjemahkan dan menangkap esensi kebijakan makro pendidikan serta memahami kondisi lingkunganya (kelebihan dan kekurangannya) untuk kemudian melalui proses perencanaan, sekolah harus memformulasikannya ke dalam kebijakan mikro dalam bentuk program-program prioritas yang harus dilaksanakan dan dievaluasi oleh sekolah yang bersangkutan sesuai dengan visi dan misinya masing-masing. Sekolah harus menentukan target mutu untuk tahun berikutnya. Dengan demikian, sekolah secara mandiri tetapi masih dalam kerangka acuan kebijakan nasional dan ditunjang dengan penyediaan input yang memadai, memiliki tanggung jawab terhadap pengembangan sumber daya yang dimilikinya sesuai dengan kebutuhan belajar siswa dan masyarakat.

Dengan pendekatan yang dikemukakan di atas, akan memberi otonomi yang lebih besar kepada sekolah dan mendorong pengambilan keputusan partisipatif yang melibatkan secara langsung semua warga sekolah (guru, siswa, kepala sekolah, karyawan, orang tua siswa dan masyarakat) untuk meningkatkan mutu sekolah berdasarkan kebijakan pendidikan nasional. Dengan pelibatan warga sekolah dalam pengambilan keputusan, akan menimbulkan peningkatan rasa memiliki. Selanjutnya akan meningkatkan rasa tanggung jawab dan pada gilirannya akan meningkatkan dedikasi terhadap sekolahnya. ${ }^{6}$

Kebijakan atau pendekatan yang melibatkan warga sekolah yang besar terhadap manajemen sekolah, pada awalnya merupakan kelanjutan 
dari otonomi daerah yang berdampak pada otonomi pendidikan. Kebijakan ini relatif dimulai sejak tahun 1999/2000, yaitu dengan pelun-curan dana bantuan yang disebut dengan Bantuan Operasional Manajemen Mutu (BOMM). Dana bantuan ini secara langsung ke rekening sekolah, tidak melalui jalur birokrasi pendidikan di atasnya. Memasuki tahun anggaran 2003, dana BOMM itu diubah namanya menjadi Dana Rintisan untuk MPMBS, khususnya untuk Sekolah Lanjutan Tingkat Pertama (SLTP). Program ini sejalan dengan implementasi dari Undang-undang (UU) Nomor 22 Tahun 1999 tentang Otonomi Daerah di bidang Pendidikan dan Undang-undang Nomor 25 Tahun 2000 tentang Program Pemba-ngunan Nasional (Propenas). Skema kebijakan MPMBS dapat dilihat berikut ini:

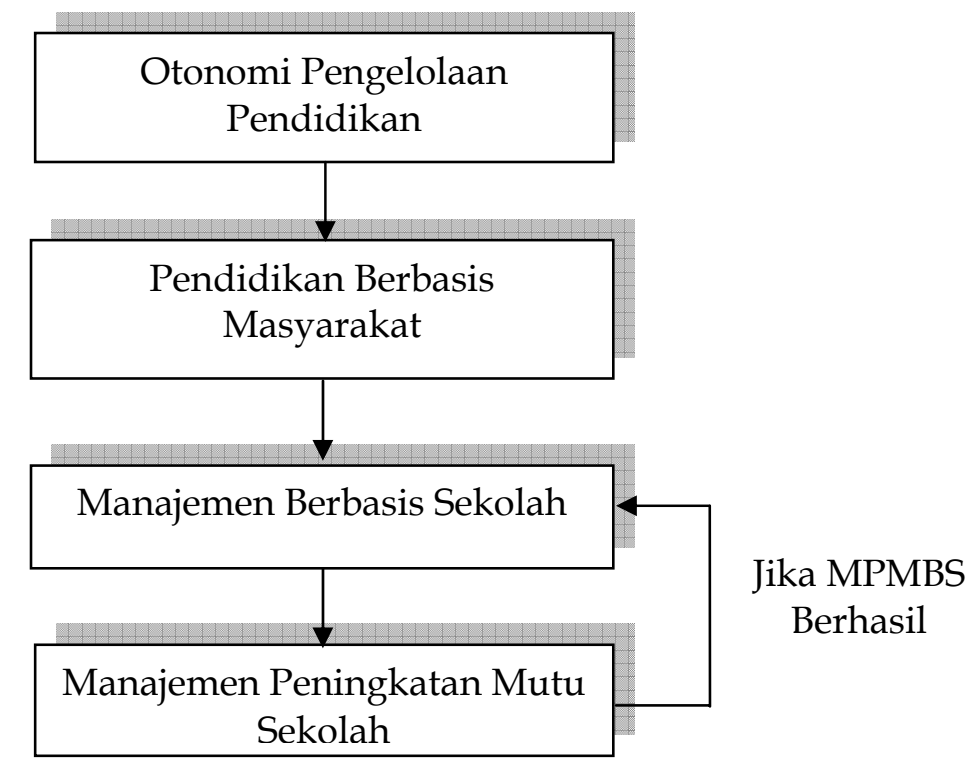

Gambar 1. Skema berpikir kebijakan MPMBS di Indonesia

\section{MUTU PENDIDIKAN}

Mutu pendidikan sangat tergantung oleh kemampuan suatu bangsa dalam mengelolanya. Kemampuan tersebut tidak hanya dengan niat semata, melainkan dengan usaha yang keras dan berkesinambungan dengan menggunakan berbagai cara. Cara tersebut dengan mengaplikasikan sistem atau teknik yang sering digunakan dalam manajemen modern saat ini.

Meskipun tidak ada pengertian mutu yang diterima secara universal, namun secara umum hampir sama. Crosby menyatakan bahwa mutu adalah conformance to requirement atau sesuai dengan yang disyaratkan atau 
memenuhi standar.7 Pakar manajemen seperti Juran mengemukakan bahwa mutu adalah keselarasan produk atau fitness for use untuk memenuhi kebutuhan dan kepuasan pelanggan. ${ }^{8}$ Hal ini mengindikasikan bahwa mutu adalah sebuah keunggulan produk atau jasa yang dapat memuaskan pelanggan. Demikian juga yang dikemukakan oleh Johnson yang mengemukakan bahwa mutu adalah kemampuan suatu produk dan jasa untuk memenuhi kebutuhan pelanggan. ${ }^{9}$ Terakhir Deming juga mengemukakan hal yang sama bahwa mutu kesesuaian dengan kebutuhan pasar atau konsumen. ${ }^{10}$

Lebih jauh Garvin dan Davis menyatakan bahwa mutu adalah suatu kondisi dinamis yang berhubungan dengan produk, manusia/tenaga kerja, proses dan tugas, serta lingkungan yang memenuhi atau melebihi harapan pelanggan atau konsumen.11 Keinginan dan harapan konsumen atau pelanggan selalu berubah sehingga mutu produk atau jasa juga harus berubah dan disesuaikan. Dengan perubahan mutu tersebut, diperlukan perubahan atau peningkatan keterampilan tenaga kerja, perubahan proses produksi dan tugas, serta perubahan lingkungan perusahaan agar produk dapat memenuhi atau melebihi keinginan konsumen. Dalam hal ini diperlukan perbaikan terus menerus dari produk atau jasa yang dihasilkan. Berdasarkan beberapa pengertian di atas dapat disimpulkan bahwa mutu adalah usaha memenuhi atau melebihi keinginan dan harapan konsumen yang mencakup produk, tenaga kerja, proses dan lingkungan dengan cara perbaikan terus menerus karena terjadi perubahan di setiap saat.

Membahas mutu pendidikan berarti mengacu pada masukan, proses, luaran dan dampaknya. Menurut Danim mutu masukan dilihat dari beberapa sisi. Pertama, kondisi baik atau tidaknya masukan sumber daya manusia (kepala sekolah, guru, laboran, staf tata usaha dan siswa). Kedua memenuhi atau tidaknya kriteria masukan material berupa alat peraga, buku-buku, kurikulum, prasarana, sarana sekolah. Ketiga memenuhi atau tidaknya kriteria masukan yang berupa perangkat lunak, seperti peraturan, struktur organisasi dan deskripsi kerja. Keempat mutu masukan yang bersifat harapan dan kebutuhan seperti visi, motivasi, ketekunan dan cita-cita. ${ }^{12}$

Mutu proses pendidikan dianggap baik apabila sumber daya sekolah mampu mentransformasikan multijenis masukan dan situasi untuk mencapai derajat nilai tambah tertentu bagi peserta didik. Hal-hal yang termasuk dalam kerangka mutu proses pendidikan ini adalah derajat kesehatan, keamanan, disiplin, keakraban, saling menghormati, kepuasan dan lain-lain.

Hasil pendidikan dipandang bermutu jika mampu melahirkan keunggulan akademik dan ekstrakurikuler pada peserta didik yang dinyatakan lulus untuk satu jenjang pendidikan atau menyelesaikan program 
pembelajaran tertentu. Selain itu, mutu pendidikan juga dapat dilihat dari tertib administrasi. Salah satu bentuk tertib administrasi adalah adanya mekanisme kerja yang efektif dan efisien, baik secara vertikal maupun horizontal.

Dalam konteks pengembangan Total Quality Management (TQM) untuk layanan pendidikan, berarti semua perangkat sekolah dari kepala sekolah, guru, karyawan dan tenaga kebersihan serta keamanan, harus benar-benar memiliki kultur pelayanan terbaik terhadap siswa dan orang tua siswa, sehingga mereka puas, tidak saja di akhir setelah putra-putrinya lulus, tapi sejak awal mereka masuk ke halaman sekolah, merasa nyaman, aman, terlindungi, terhargai dan terlayani oleh perangkat sekolah yang berada di front line. Kemudian layanan administrasinya efisien dan efektif, cepat, tepat dan akurat, dan para pegawai yang berada di front liner-nya bisa menghadapi pelanggan dengan ramah. Kemudian guru mengajar dengan persiapan yang baik, memperhatikan keragaman siswa, bersikap demokratis dalam pengembangan strategi, tidak membiarkan ada anak yang tertinggal, sehingga end-product dari mata pelajarannya memiliki kompetensi penguasaan yang baik. Demikian pula dengan kepala sekolahnya, selain dinamis, progresif dia juga aspiratif, terbuka dengan saransaran kemajuan, dan mampu mengkomunikasikan gagasan serta berbagai persoalan sekolahnya itu pada komite sekolah, untuk disampaikan pada client yang lebih luas, serta kelompok peduli sekolah dari masyarakat lingkungannya. ${ }^{13}$

Dengan perilaku dalam pelayanan yang bermutu di atas, membuat pelayanan di sekolah akan lebih bertanggung jawab. Dari pelayanan tersebut sangat dimungkinkan untuk mendapatkan pendidikan yang bermutu. Edward Sallis menyatakan bahwa sekolah yang bermutu bercirikan hal-hal sebagai berikut: ${ }^{14}$

- Sekolah berfokus pada pelanggan, baik pelanggan internal maupun eksternal. Pada sekolah yang bermutu, totalitas perilaku staf, tenaga akademik dan pimpinan melakukan tugas pokok dan fungsi untuk memenuhi kebutuhan pelanggan. Inisiatif ini perlu didukung oleh mekanisme kerja secara vertikal dan horizontal dengan menempatkan kepentingan akademik sebagai inti kegiatan.

Pelanggan dalam hal ini terdiri atas pelanggan eksternal utama yaitu siswa atau pelajar, pelanggan eksternal kedua yaitu orang tua, kepala daerah, pelanggan eksternal ketiga yaitu pemerintah, masyarakat dan bursa kerja, yang terakhir pelanggan internal yaitu guru dan staf. ${ }^{15}$

- Sekolah berfokus pada upaya untuk mencegah masalah yang muncul, dalam makna ada komitmen untuk bekerja secara benar dari awal.

- Sekolah memiliki investasi pada sumber daya manusianya. Komitmen 
ini perlu terus dijaga jangan sampai mengalami "kerusakan", karena "kerusakan psikologis" sangat sulit memperbaikinya.

- Sekolah memiliki strategi untuk mencapai mutu, baik di tingkat pimpinan, tenaga akademik, maupun tenaga administratif.

- Sekolah mengelola atau memperlakukan keluhan sebagai umpan balik untuk mencapai kualitas dan memposisikan kesalahan sebagai instrumen untuk berbuat benar pada peristiwa atau kejadian berikutnya.

- Sekolah memiliki kebijakan dalam perencanaan untuk mencapai kualitas, baik perencanaan jangka pendek, jangka menengah, maupun jangka panjang.

- Sekolah mengupayakan proses perbaikan dengan melibatkan semua orang sesuai dengan tugas pokok, fungsi dan tanggung jawabnya.

- Sekolah mendorong orang yang dipandang memiliki kreatifitas, mampu menciptakan kualitas dan merangsang yang lainnya agar dapat bekerja secara berkualitas.

- Sekolah memperjelas peran dan tanggung jawab setiap orang, termasuk kejelasan arah kerja secara vertikal dan horizontal.

- Sekolah memiliki strategi dan kriteria evaluasi yang jelas.

- Sekolah memandang atau menempatkan kualitas yang telah dicapai sebagai jalan untuk memperbaiki kualitas layanan lebih lanjut.

- Sekolah memandang kualitas sebagai bagian integral dari budaya kerja.

- Sekolah menempatkan peningkatan kualitas secara terus menerus sebagai suatu keharusan.

Ciri-ciri sekolah yang bermutu seperti yang dikemukakan di atas, harus didukung oleh struktur organisasi sekolah yang bermutu pula. Struktur organisasi dan mekanisme kerja sekolah yang dikehendaki menurut konsep mutu terpadu (MMT) sebagaimana yang dikemukakan Danim yaitu:

- Struktur organisasi sekolah mampu melancarkan proses pengelolaan mutu secara menyeluruh dan kondusif bagi perbaikan mutu.

- Struktur organisasi sekolah mampu mengutamakan kerja sama yang solid secara tim kerja.

- Struktur organisasi sekolah mampu mengurangi fungsi yang tidak perlu.

- Struktur organisasi sekolah mampu mereduksi pekerjaan-pekerjaan yang dilakukan secara repetitif atau tumpang-tindih akibat kesalahan struktur kerja.

- Struktur organisasi sekolah mampu membentuk tim yang terstruktur dengan sistem manajemen yang sederhana, tetapi efektif.

- Struktur organisasi sekolah mampu mengupayakan agar semua anggota 
tim memahami visi lembaga.

- Struktur organisasi sekolah mampu mengupayakan agar semua anggota tim mampu memahami potensi lembaga, baik yang riil ada maupun yang mungkin diakses.

- Struktur organisasi sekolah mampu mengupayakan agar keseluruhan proses kerja berada di bawah satu komando yang hubungan kerjanya sederhana.

- Struktur organisasi sekolah mampu melakukan penilaian untuk menentukan keberhasilan kerja sebuah sekolah. ${ }^{16}$

Untuk dapat mewujudkan struktur yang demikian ideal, tentu saja sangat tergantung oleh kepemimpinan yang ideal juga. Oleh karena itu, dibutuhkan kepemimpinan kepala sekolah untuk bekerja dengan atau melalui staf administratif dan tenaga akademiknya. Seorang kepala sekolah idealnya memahami dengan baik mengenai visi lembaganya. Kepala sekolah membudayakan kerja secara bermutu dan dapat memberdayakan seluruh potensi yang ada untuk mendukung mutu yang dikehendaki. Menurut Danim ada lima kemampuan dasar yang harus dimiliki kepala sekolah, yaitu; pertama, kepala sekolah memahami visi organisasi dan memiliki visi kerja yang jelas. Kedua, kepala sekolah mampu dan mau bekerja keras. Ketiga, kepala sekolah tekun dan tabah dalam bekerja dengan bawahan, terutama tenaga administratif dan tenaga akademiknya. Keempat, kepala sekolah memberikan layanan secara optimal dengan tetap tampil secara rendah hati. Kelima, kepala sekolah memiliki disiplin kerja yang kuat. 17

Menurut Msurgatroyd dan Morgan mutu pendidikan didasarkan atas pengertian yang telah dibangun oleh mutu itu sendiri. Pengertian mutu adalah adanya quality assurance, contract conformance dan customerdriven quality. Oleh karena itu, seharusnya mutu pendidikan harus memiliki jaminan mutu, kesepakatan atau kontrak dan berorientasi pelanggan. Pertama, Jaminan mutu pendidikan mengacu pada penentuan standar, metode dan kualitas yang sesuai persyaratan oleh ahli, disertai dengan proses inspeksi atau evaluasi yang meneliti sejauh mana memenuhi standar yang ada. Kedua, Kesesuaian kontrak adalah terpenuhinya standar mutu pendidikan yang telah ditentukan selama negosiasi pembentukan kontrak. Ketiga, Orientasi pelanggan mengacu pada orang-orang yang menerima suatu produk atau jasa sesuai dengan harapannya terhadap pendidikan atau harapan-harapan terhadap suatu jasa pendidikan dapat terpenuhi. ${ }^{18}$

Proses pendidikan adalah sebuah proses jasa, menilai sebuah mutu 
pendidikan adalah menilai layanan dari sebuah sekolah. Arismunandar mengemukakan bahwa manajemen pendidikan yang bermutu berdasarkan pada sebuah standar pelayanan minimal dengan sejumlah indikator, yaitu: ${ }^{19}$

\section{Manajemen Kurikulum dan Proses Belajar Mengajar}

Standarisasi manajemen mutu kurikulum dan kegiatan belajar mengajar bertujuan untuk memastikan bahwa lembaga sekolah mencapai derajat prestasi tinggi dalam pelaksanaan kurikulum nasional dan kurikulum lokal. Sebagai konsekuensi penerimaan kurikulum nasional dan lokal, setiap lembaga pendidikan perlu mengukur keberhasilan pencapaian tujuan kurikulernya melalui alokasi waktu belajar sesuai dengan standar nasional dan daya serap kurikulum nasional yang bergerak antara minimal $75 \%-90 \%$.

Sebagai konsekuensi dari itu, sekolah perlu mengembangkan sistem perencanaan waktu belajar di kelas dan di luar kelas yang sedemikian rupa untuk mengejar target kurikulum sebagaimana dituangkan dalam garisgaris besar program pengajaran (GBPP).

\section{Organisasi dan Kelembagaan Sekolah}

Standarisasi organisasi dan manajemen mutu sekolah bertujuan untuk memastikan bahwa struktur, personalia dan uraian tugas telah disusun sedemikian rupa sehingga mencerminkan sistem organisasi yang profesional. Dari segi struktur, kelembagaan sekolah harus mencerminkan bidang tugasnya termasuk pertimbangan unit-unit kerja yang diperlukan berdasarkan analisis jabatan. Dari segi personalia, diperlukan standarisasi mengenai kualifikasi profesional pejabat yang mendukung jabatan terutama pada posisi kepala dan wakil kepala sehingga tidak lagi terjadi pengisian jabatan-jabatan itu oleh personil yang tidak memenuhi persyaratan. Harus dipahami bahwa posisi kepala sekolah hendaknya lebih menekankan pelaksanaan fungsi kepemimpinan ketimbang kekuasaan. Dari segi pembagian tugas, harus dapat dijamin bahwa semua personil mendapat tugas yang adil dan dari segi uraian tugas harus pula dapat dijamin bahwa semua personil sekolah mengetahui tugas-tugasnya dengan jelas dan berdasarkan hal itu kinerja mereka dinilai.

\section{Manajemen Mutu Sarana dan Prasarana}

Standarisasi manajemen mutu sarana dan prasarana dimaksudkan untuk memastikan bahwa ketersediaan sarana sesuai dengan kebutuhan pembelajaran yang meliputi; a) ketersediaan lahan, bangunan, peralatan/ 
laboratorium/media, buku teks dan sarana olahraga. Lahan sekolah seharusnya cukup menyediakan lapangan terbuka untuk tempat kegiatan belajar di luar kelas dan tempat bermain bagi murid. Bangunan sekolah seharusnya meliputi ruang-ruang untuk kepala dan wakil kepala sekolah menengah, ruang tata usaha, ruang guru, ruang bimbingan konseling, perpustakaan, laboratorium, kamar mandi/WC, ruang UKS, dan ruang kelas dengan ukuran dan kualitas yang memadai. Khusus untuk buku teks, rasio yang dipersyaratkan adalah minimal 1 buku teks pelajaran pokok untuk setiap siswa.

\section{Manajemen Mutu Ketenagaan}

Standarisasi manajemen mutu ketenagaan bertujuan untuk memastikan bahwa jumlah dan kualifikasi tenaga yang ada pada setiap sekolah sesuai dengan semestinya. Jenis ketenagaan di lingkungan pendidikan adalah: kepala sekolah, guru, pembimbing, laboran, pegawai tata usaha dan tenaga lainnya. Kualifikasi ketenagaan mutlak diperhatikan, terutama dalam hal kompetensi profesional. Sebagai ilustrasi, pada sekolah menengah umum dewasa ini telah dikembangkan standarisasi kompetensi guru SLTP, kompetensi atau kemampuan dasar siswa dan standarisasi kompetensi kepala sekolah. Daftar kompetensi tersebut dijadikan dasar oleh Diknas dalam melakukan uji kompetensi terhadap guru.

\section{Manajemen Mutu Peserta Didik}

Standarisasi manajemen mutu peserta didik dimaksudkan untuk menjamin bahwa sekolah memiliki kecenderungan peningkatan dalam hal angka pendaftaran siswa, angka kenaikan kelas, kelulusan dan sebaliknya penurunan dalam hal angka putus sekolah dan angka mengulang kelas. Standarisasi manajemen mutu kesiswaan juga dimaksudkan untuk memastikan bahwa sistem rekrutmen siswa sesuai dengan peraturan dan penempatannya dalam kelas tidak melebihi 40 siswa. Standarisasi ini juga mencakup penyediaan unit-unit kegiatan kesiswaan, khususnya yang bersifat kokurikuler.

\section{Manajemen Mutu Pembiayaan}

Standarisasi dalam manajemen mutu pembiayaan bertujuan untuk menjamin ketersediaan biaya penyelenggaraan pendidikan. Setiap tahun sekolah perlu membuat Rencana Anggaran Pendapatan dan Belanja Sekolah (RAPBS) di mana di dalamnya sudah mengalokasikan sumber

pembiayaan. Sumber-sumber pembiayaan tersebut meliputi; bantuan pemerintah pusat, pemerintah daerah, dana masyarakat dan sumber lain 
seperti hibah, usaha sekolah dan pinjaman sesuai dengan ketentuan yang berlaku. Sekolah yang baik adalah jika persentase penerimaan dana masyarakat dan usaha lainnya lebih besar dari persentase penerimaan bantuan dari pemerintah.

\section{Manajemen Mutu Peran Serta Masyarakat}

Standarisasi manajemen mutu peran serta masyarakat bertujuan untuk memastikan bahwa sekolah memberikan kesempatan kepada masyarakat untuk berpartisipasi dalam kehidupan sekolah. Karena itu, di setiap sekolah perlu dibentuk badan peran serta masyarakat seperti BP3, komite sekolah atau organisasi lain yang sejenis. Pembentukan badanbadan seperti itu hendaknya melibatkan masyarakat dalam arti seluasluasnya dan tidak hanya terbatas pada orang tua siswa.

Dari beberapa pernyataan yang telah dikemukakan sebelumnya, penulis menyimpulkan bahwa menilai mutu pendidikan berarti harus dilihat secara keseluruhan, artinya, mulai dari input, proses yang ada dan output-nya harus dijadikan bermutu. Penekanan yang diinginkan di sini adalah mutu proses dalam pendidikan, karena proses sangat menentukan sebuah pendidikan yang bermutu. Proses dalam hal ini berkaitan dengan struktur organisasi yang bermutu dan pelaksanaannya atau layanannya dengan demikian guru, pegawai atau staf harus bermutu pula. Untuk mewujudkan hal itu tentunya dibutuhkan kepemimpinan yang bermutu pula, karena intinya adalah kemampuan pemimpin dalam mengelola semua yang terlibat dalam proses pendidikan yang bermutu tersebut.

\section{MANAJEMEN PENINGKATAN MUTU BERBASIS SEKOLAH}

Pada masa sekarang kebutuhan siswa akan belajar sangat bervariasi, demikian pula kebutuhan guru dan staf lain dalam pengembangan keprofesionalan sangat beragam, sementara itu lingkungan sekolah satu dengan lainnya sangat berbeda. Selain itu, harapan orang tua/masyarakat akan pendidikan yang bermutu sangat besar demikian pula tuntutan dunia usaha untuk memperoleh tenaga bermutu. Oleh karena itu, menjadi keharusan bagi setiap individu terutama pimpinan kelompok untuk merespons dengan sunguh-sunguh hal ini dan mengapresiasikan kondisi tersebut di dalam proses pengambilan keputusan.

Dalam proses pengambilan keputusan untuk peningkatan mutu pendidikan idealnya dapat melibatkan berbagai kelompok masyarakat terutama yang memiliki kepedulian kepada pendidikan. Karena sekolah berada pada bagian terdepan dari pada proses pendidikan, maka diskusi ini memberi konsekuensi bahwa sekolah harus menjadi bagian utama di 
dalam proses pembuatan keputusan dalam rangka peningkatan mutu pendidikan. Sementara, masyarakat dituntut partisipasinya agar lebih memahami pendidikan, sedangkan pemerintah pusat berperan sebagai pendukung dalam hal menentukan kerangka dasar kebijakan pendidikan.

Pendekatan yang selama ini dikenal mungkin berbeda dengan konsep modern yang akan dikemukakan pada tulisan ini. Pada waktu yang lalu, birokrasi pusat sangat mendominasi proses pengambilan atau pembuatan keputusan pendidikan, baik bersifat makro sampai ke mikro. Sementara sekolah hanya vakum dan tidak memiliki kekuasaan dalam pengambilan keputusan. Sekolah hanya melaksanakan kebijakan-kebijakan yang diberikan yang belum tentu sesuai dengan kebutuhan belajar siswa, lingkungan Sekolah, dan harapan orang tua.

Pengalaman menunjukkan bahwa sistem lama seringkali menimbulkan kontradiksi antara apa yang menjadi kebutuhan sekolah dengan kebijakan yang harus dilaksanakan di dalam proses peningkatan mutu pendidikan. Fenomena pemberian kemandirian kepada sekolah ini memperlihatkan suatu perubahan cara berpikir dari yang bersifat rasional, normatif dan pendekatan preskriptif di dalam pengambilan keputusan pandidikan kepada suatu kesadaran akan kompleksnya pengambilan keputusan di dalam sistem pendidikan dan organisasi yang mungkin tidak dapat diapresiasiakan secara utuh oleh birokrat pusat. Hal inilah yang kemudian mendorong munculnya pemikiran untuk beralih kepada konsep manajemen peningkatan mutu berbasis sekolah sebagai pendekatan baru di Indonesia, yang merupakan bagian dari desentralisasi pendidikan yang tengah dikembangkan.

\section{Pengertian}

Manajemen peningkatan mutu berbasis sekolah merupakan alternatif baru dalam pengelolaan pendidikan yang lebih menekankan kepada kemandirian dan kreatifitas sekolah. Konsep ini diperkenalkan oleh teori effective school yang lebih memfokuskan diri pada perbaikan proses pendidikan. Beberapa indikator yang menunjukkan karakter dari konsep manajemen ini antara lain sebagai berikut: a) lingkungan sekolah yang aman dan tertib, b) sekolah memiliki misi dan target mutu yang ingin dicapai, c) sekolah memiliki kepemimpinan yang kuat, d) adanya harapan yang tinggi dari personel sekolah (kepala sekolah, guru, dan staf lainnya termasuk siswa) untuk berprestasi, e) adanya pengembangan staf sekolah yang terus menerus sesuai tuntutan IPTEK, f) adanya pelaksanaan evaluasi yang terus menerus terhadap berbagai aspek akademik dan administratif, dan pemanfaatan hasilnya untuk penyempurnaan/perbaikan mutu, dan g) 
adanya komunikasi dan dukungan intensif dari orang tua murid/masyarakat.

Pengembangan konsep manajemen ini didesain untuk meningkatkan kemampuan sekolah dan masyarakat dalam mengelola perubahan pendidikan kaitannya dengan tujuan keseluruhan, kebijakan, strategi perencanaan, inisiatif kurikulum yang telah ditentukan oleh pemerintah dan otoritas pendidikan. Pendidikan ini menuntut adanya perubahan sikap dan tingkah laku seluruh komponen sekolah; kepala sekolah, guru dan tenaga/ staf administrasi termasuk orang tua dan masyarakat dalam memandang, memahami, membantu sekaligus sebagai pemantau yang melaksanakan monitoring dan evaluasi dalam pengelolaan sekolah yang bersangkutan dengan didukung oleh pengelolaan sistem informasi yang presentatif dan valid. Akhir dari semua itu ditujukan kepada keberhasilan sekolah untuk menyiapkan pendidikan yang berkualitas/bermutu bagi masyarakat.

Dalam pengimplementasian konsep ini, sekolah memiliki tanggung jawab untuk mengelola dirinya berkaitan dengan permasalahan administrasi, keuangan dan fungsi setiap personel sekolah di dalam kerangka arah dan kebijakan yang telah dirumuskan oleh pemerintah. Bersama-sama dengan orang tua dan masyarakat, sekolah harus membuat keputusan, mengatur skala prioritas disamping harus menyediakan lingkungan kerja yang lebih profesional bagi guru, dan meningkatkan pengetahuan dan kemampuan serta keyakinan masyarakat tentang sekolah/pendidikan.

Kepala sekolah harus tampil sebagai koordinator dari sejumlah orang yang mewakili berbagai kelompok yang berbeda di dalam masyarakat sekolah dan secara profesional harus terlibat dalam setiap proses perubahan di sekolah melalui penerapan prinsip-prinsip pengelolaan kualitas total dengan menciptakan kompetisi dan penghargaan di dalam sekolah itu sendiri maupun sekolah lain.

Menurut Etheridge, MBS adalah sebuah proses formal yang melibatkan kepala sekolah, guru, orang tua siswa, siswa dan masyarakat yang berada dekat dengan sekolah, dalam proses pengambilan berbagai keputusan. ${ }^{20}$ Sementara Short dan Greer mendefinisikan MBS sebagai sebuah strategi yang mengangkat konsep tentang pemberdayaan dan memberdayakan semua individu di sekolah. ${ }^{21}$

Ada empat hal yang terkait dengan prinsip-prinsip pengelolaan kualitas total yaitu; (i) perhatian harus ditekankan kepada proses dengan terus - menerus mengumandangkan peningkatan mutu, (ii) kualitas/mutu harus ditentukan oleh pengguna jasa sekolah, (iii) prestasi harus diperoleh melalui pemahaman visi bukan dengan pemaksaan aturan, (iv) sekolah harus menghasilkan siswa yang memiliki ilmu pengetahuan, keterampilan, 
sikap arif bijaksana, karakter, dan memiliki kematangan emosional. Sistem kompetisi tersebut akan mendorong sekolah untuk terus meningkatkan diri, sedangkan penghargaan akan dapat memberikan motivasi dan meningkatkan kepercayaan diri setiap personel sekolah, khususnya siswa. Jadi sekolah harus mengontrol semua sember daya termasuk sumber daya manusia yang ada, dan lebih lanjut harus menggunakan secara lebih efisien sumber daya tersebut untuk hal-hal yang bermanfaat bagi peningkatan mutu khususnya. Sementara itu, kebijakan makro yang dirumuskan oleh pemerintah atau otoritas pendidikan lainnya masih diperlukan dalam rangka menjamin tujuan-tujuan yang bersifat nasional dan akuntabilitas yang berlingkup nasional.

Abu-Duho mengemukakan bahwa inti MBS adalah pembuatan keputusan yang partisipatoris di lingkungan sekolah yang berkaitan dengan pengaturan sumber daya. ${ }^{22}$ Selanjutnya Education Consumer Guide mendefinisikan MBS sebagai suatu strategi untuk memperbaiki pendidikan dengan mengalihkan otoritas pengambilan keputusan dari negara dan daerah ke individu sekolah. ${ }^{23}$ Dengan MBS, kepala sekolah, guru, siswa dan orang tua diberikan kewenangan mengontrol proses pendidikan melalui pemberian tanggung jawab dalam memutuskan pembiayaan, personalia dan kurikulum. Melalui keterlibatan guru, orang tua dan anggota masyarakat lainnya dalam pengambilan keputusan kunci, MBS dapat menciptakan lingkungan pembelajaran yang lebih efektif bagi siswa.

Istilah Manajemen Peningkatan Mutu Berbasis Sekolah (MPMBS) pada dasarnya sama dengan MBS. Kata "peningkatan mutu" digunakan untuk memberikan penekanan bahwa tujuan akhir pelaksanaan MBS adalah peningkatan mutu sekolah pada umumnya dan pembelajaran pada khususnya. Selain itu, istilah MPMBS digunakan sebagai nama program rintisan Ditjen Dikdasmen melalui pemberian dana BOMM (bantuan operasional manajemen mutu) kepada SLTP/SMU secara terbatas. Diharapkan melalui program rintisan MPMBS ini dapat mendorong sekolah melaksanakan MBS. ${ }^{24}$

Inti dari MBS menurut Departemen Pendidikan Nasional adalah otonomi dan pengambilan keputusan partisipatif. Dalam hal ini sekolah diharapkan memiliki kewenangan dan kemandirian dalam mengatur dirinya sendiri dan tidak tergantung sepenuhnya pada pemerintah. Selain itu, setiap pengambilan keputusan, sekolah dapat menciptakan lingkungan yang terbuka dan demokratik, dimana warga sekolah didorong untuk terlibat secara langsung dalam proses pengambilan keputusan yang dapat berkontribusi terhadap pencapaian tujuan sekolah. ${ }^{25}$ 


\section{Tujuan}

Tujuan MBS adalah memberdayakan sekolah, terutama sumber daya manusianya. ${ }^{26}$ Pemberdayaan terjadi melalui pemberian kewenangan, fleksibilitas dan sumber daya lain untuk memecahkan persoalan yang dihadapi oleh sekolah yang bersangkutan.

Secara spesifik, menurut Arismunandar MBS bertujuan untuk: 1) mendorong peningkatan mutu sekolah karena fokus penekanannya pada ketiga komponen sistem: input-proses-output dari pada pendekatan input yang dianut selama ini, 2) meningkatkan partisipasi warga sekolah dalam pengambilan keputusan, dan 3) meningkatkan akuntabilitas sekolah terhadap masyarakat, sebagai konsekuensi keterlibatan masyarakat dalam proses persekolahan. ${ }^{27}$ Selain itu, Drury dan Levin mengemukakan tujuan jangka pendek penerapan MBS, yaitu 1) meningkatkan efisiensi penggunaan sumber daya, 2) meningkatkan profesionalisme guru, dan 3) mendorong implementasi pembaharuan kurikulum di sekolah. ${ }^{28}$

\section{Karakteristik}

Ditambahkan bahwa MBS juga dicirikan 1) berkembangnya kultur sekolah yang demokratis dan dinamis, 2) keterbukaan manajemen penyelenggaraan pendidikan, 3) terjalinnya kerjasama di sekolah secara internal dan eksternal, 4) meningkatnya partisipasi semua pihak dalam mewujudkan tujuan pendidikan di sekolah dan 5) adanya pengendalian mutu melalui quality assurance dan akreditasi sekolah. ${ }^{29}$

Menurut Bailey karakteristik dari sebuah sekolah yang menganut MBS adalah:

- Adanya keragaman dalam pola penggajian guru

- Otonomi manajemen sekolah

- Pemberdayaan guru secara optimal

- Pengelolaan sekolah secara partisipatif

- Sistem yang didesentralisasikan

- Sekolah dengan pilihan atau otonomi sekolah dalam menentukan aneka pilihan

- Hubungan kemitraan antara dunia bisnis dan dunia pendidikan

- Akses terbuka bagi sekolah untuk tumbuh relatif mandiri

- "pemasaran" sekolah secara kompetitif.30

Murphy menegaskan, kewenangan sekolah untuk secara otonom memutuskan sendiri bersama mitra horizontalnya, ada lima, yaitu; perumusan tujuan, perencanaan pembiayaan, personalia, kurikulum dan struktur organisasi. Tujuan yang dimaksud adalah tujuan sekolah sebagai sebuah institusi, yang dikembangkan dari visi, misi dan kemudian dapat 
dituangkan dalam bentuk program-program strategis sekolah itu sendiri. Implikasi dari perumusan tujuan dan program adalah pembiayaan. Oleh sebab itu, jika perumusan visi, misi dan tujuan serta program strategis sekolah diserahkan pada sekolah sendiri, maka demikian pula dengan perencanaan pembiayaannya. Otonomi sekolah adalah merancang pembiayaan, mengontrol pemakaian dan mempertanggungjawabkan penggunaannya itu pada stakeholder yang terlibat dalam penyusunan dan pemenuhan seluruh kebutuhan pembiayaan sekolah. ${ }^{31}$

Otonomisasi budgetting sekolah menuntut adanya kekuatan SDM untuk tugas-tugas fundrising, sehingga sekolah juga harus diberi otonomisasi dalam penyusunan struktur organisasi serta memilih dan mengangkat SDM sesuai keperluan program. Semua perencanaan serta dukungan fasilitas, alat dan sumber daya manusia serta keuangan semata dikembangkan untuk memberikan quality assurance terhadap proses pembelajaran agar dapat menghasilkan lulusan yang kompetitif. Oleh sebab itu, sekolah juga harus diberi otonomisasi dalam penyusunan kurikulum, pengembangan strategi pembelajaran, alat yang digunakan untuk belajar serta berbagai fasilitas pembelajaran lainnya, bahkan juga penetapan standar kelulusan, instrumen yang akan digunakan untuk meng-assess keberhasilan siswa, serta keleluasaan pengalokasian waktu.

Dalam melaksanakan MBS dengan karakteristik yang ideal harus didukung dengan berbagai hal, terutama mental dari pelaksana MBS. Hal ini diperlukan mengingat mengubah struktur adalah perbuatan mudah karena struktur organisasi sifatnya statis, tetapi mengubah mental hal ini sangat sulit padahal tanpa mental yang baik dari pelaksana, maka akan sulit untuk mewujudkan MBS. David mengemukakan bahwa MBS akan berjalan dengan baik apabila tercipta pergeseran pada tingkat struktural dalam beberapa hal berikut:

- Membangun aliansi yang kuat dengan persatuan guru

- Mendelegasikan kekuasaan dan kewenangan kepala sekolah untuk mendefinisikan tugas-tugas baru, memilih staf dan mengkreasi lingkungan belajar.

- Mendorong terciptanya otonomi dalam pembuatan keputusan sekolah.

- Mengkomunikasikan tujuan, menentukan patok sasaran dan mendistribusikan informasi secara akurat.

- Menciptakan komunikasi yang dinamis antara staf sekolah dan pejabat kependidikan.

- Memberi peluang kepada sekolah untuk "bereksperimen" dan membuat keputusan "beresiko"

- Memodifikasi keputusan pejabat struktural pendidikan. 
- Memotivasi kepala sekolah untuk melibatkan guru-guru dalam aneka pembuatan keputusan.

- Mengembangkan kaidah akuntabilitas bagi staf sekolah.

- Memberikan peluang luas bagi kepala sekolah dan staf untuk mengembangkan kemampuan dan keahlian profesionalnya.

- Memberi peluang kepala sekolah dan staf untuk membuat aturan baru dan mempertanggungjawabkannya.

- Mengembangkan kaidah-kaidah di mana kantor pusat hanya berkedudukan sebagai fasilitator dan koordinator pembaruan sekolah, bukan sebatas mengkomando dan menyampaikan instruksi yang kaku.

- Menggunakan pendekatan prestasi, misalnya dalam bidang penggajian. Pendekatan prestasi ini merupakan instrumen agar guru dan kepala sekolah tampil bermutu dan unggul dalam prestasi. ${ }^{32}$

Demikian beberapa hal yang menyangkut MPMBS yang mengedepankan otonomi sekolah. Dalam hal ini, sekolah diberi kewenangan yang seluas-luasnya dalam mengelola sekolah dengan baik. MPMBS bukan diberi kewenangan yang bebas tanpa pengawasan, tetapi dengan pengawasan dari masyarakat. Oleh karena itu, pelibatan masyarakat yang besar dalam pengambilan kebijakan perlu dilakukan dan hal yang sangat penting.

\section{PENUTUP}

Dengan adanya otonomi daerah hampir semua kewenangan pemerintahan diserahkan kepada daerah yang bersangkutan. Hal tersebut juga berdampak pada pendidikan. Kewenangan yang besar tersebut, tentu saja berdampak positif pada pendidikan apabila ditangani dengan serius dan penuh tanggung jawab.

Pelaksanaan segala kebijakan pendidikan yang melibatkan seluruh lapisan masyarakat akan membawa kepada perubahan pendidikan yang tidak lagi sentralistik, tetapi akan membawa pendidikan yang lebih demokratis. Dengan demikian, dengan adanya konsep ini diharapkan akan memberikan ruang yang cukup bagi sekolah dan masyarakat sekitar untuk lebih memperhatikan pendidikan. Pelibatan masyarakat ini tentu saja perlu mengingat masyarakat adalah stakeholder yang akan menikmati keberhasilan pendidikan atau sebaliknya.

Konsep MBS sebagai bentuk pendidikan yang mengedepankan harapan masyarakat akan mutu pendidikan. Sebagaimana diketahui bahwa mutu sangat tergantung kepada penilaian masyarakat atau pelanggan. Oleh karena itu, sangat wajar apabila mutu ditentukan juga oleh masyarakat tersebut. Pada akhirnya nanti hasil pendidikan akan sejalan dengan harapan, keinginan dan kebutuhan masyarakat. 
Konsep MBS ini memberikan kemandirian kepada sekolah dengan melibatkan masyarakat di dalamnya dalam hal input, proses, output dan dampak dari pendidikan. Hal ini sangat membutuhkan kerjasama dan tanggung jawab yang besar bagi sekolah dan masyarakat. Apabila kerja sama dan tanggung jawab tersebut terwujud, maka dapat dipastikan bahwa mutu yang diidamkan akan dapat dengan jelas dilihat dan dirasakan bagi semua warga sekolah sehingga akan memajukan pendidikan Indonesia lebih baik dari negara-negara lain.

Sebagai kesimpulan bahwa konsep MBS sangat penting untuk dilaksanakan, tetapi perlu digarisbawahi bahwa sekolah dan masyarakat harus melaksanakannya dengan sungguh-sunguh dan penuh keikhlasan, karena tanpa kesungguhan dan keikhlasan, maka konsep ini sangat sulit diterapkan. Selanjutnya sebagai saran bahwa konsep ini perlu direspons dan dipelajari lebih mendalam untuk dapat memahami dengan benar dan dilaksanakan sesuai dengan ketentuannya agar mendapat hasil yang lebih baik.

\section{CATATAN AKHIR:}

1. Dede Rosyada, Paradigma Pendidikan Demokrasi: Sebuah Model Pelibatan Masyarakat Dalam Penyelenggaraan Pendidikan, cet. III, Jakarta: Kencana Prenada Media Group, 2007, h. 1.

2. Dede Rosyada, Paradigma Pendidikan Demokrasi: Sebuah Model Pelibatan Masyarakat Dalam Penyelenggaraan Pendidikan, h. 2.

3. www.ssep.net/director.html, h. 2.

4. Mulyasa, Menjadi Kepala Sekolah Profesional dalam Menyukseskan MBS dan KBK, Bandung: PT. Remaja Rosdakarya, 2005, h. 31.

5. Arismunandar, Manajemen Pendidikan: Peluang dan Tantangan, cet. II, Makassar: Badan Penerbit Universitas Negeri Makassar, 2006, h. 14.

6. Ambo Enre Abdullah, Pendidikan di Era Otonomi Daerah: Gagasan dan Pengalaman, cet. I, Yogyakarta: Pustaka Timur, 2005, h. 26.

7. M.N. Nasution, Manajemen Mutu Terpadu, Bogor: Ghalia Indonesia, 2005, h. 2.

8. M.N. Nasution, Manajemen Mutu Terpadu, h. 2.

9. James H. Johnson, "Total Quality Management In Education", Journal of Oregon School Study Council, Eugene, v36 n6 Feb. 1993, h. 22.

10. M.N. Nasution, Manajemen Mutu Terpadu, h. 3.

11. M.N. Nasution, Manajemen Mutu Terpadu, h. 3.

12. Sudarwan Danim, Visi Baru Manajemen Sekolah: Dari Unit Birokrasi ke Lembaga Sekolah, cet. III, Jakarta: Bumi Aksara, 2008, h. 53-54.

13. Dede Rosyada, Paradigma Pendidikan Demokrasi: Sebuah Model Pelibatan Masyarakat Dalam Penyelenggaraan Pendidikan, h. 270.

14. Sudarwan Danim, Visi Baru Manajemen Sekolah: Dari Unit Birokrasi ke Lembaga Sekolah, h. 54. 
15. Edward Sallis, Total Quality Management in Education, diterjemahkan oleh Ahmad Ali Riyadi dan Fahrurrozi dengan judul: Manajemen Mutu Pendidikan, cet. VII, Yogyakarta: IRCiSoD, 2008, 70.

16. Sudarwan Danim, Visi Baru Manajemen Sekolah: Dari Unit Birokrasi ke Lembaga Sekolah, h. 56.

17. Sudarwan Danim, Visi Baru Manajemen Sekolah: Dari Unit Birokrasi ke Lembaga Sekolah, h. 56.

18. Stephen Msurgatroyd dan Colin Morgan, Total Quality Management and The School, Celtic Court 22 Ballmoor Buckingham: Open University Press, 1994, h. 45.

19. Arismunandar, Manajemen Pendidikan: Peluang dan Tantangan, h. 16-19.

20. Dede Rosyada, Paradigma Pendidikan Demokrasi: Sebuah Model Pelibatan Masyarakat Dalam Penyelenggaraan Pendidikan, h. 250.

21. Dede Rosyada, Paradigma Pendidikan Demokrasi: Sebuah Model Pelibatan Masyarakat Dalam Penyelenggaraan Pendidikan, h. 250

22. Arismunandar, Manajemen Pendidikan: Peluang dan Tantangan, h. 50.

23. Arismunandar, Manajemen Pendidikan: Peluang dan Tantangan, h. 50.

24. Arismunandar, Manajemen Pendidikan: Peluang dan Tantangan, h. 50.

25. Departemen Pendidikan Nasional, Manajemen Peningkatan Mutu Berbasis Sekolah, Buku 1, Jakarta: Direktorat SLTP Ditjen Dikdasmen, 2001.

26. Slamet P., Manajemen Berbasis Sekolah. www.pdk.go.id, 2003.

27. Arismunandar, Manajemen Pendidikan: Peluang dan Tantangan, h. 52.

28. Arismunandar, Manajemen Pendidikan: Peluang dan Tantangan, h. 52.

29. Departemen Pendidikan Nasional, Kebijakan dan Program Direktorat Sekolah Menengah Umum, Bahan Sosialisasi Kurikulum Berbasis Kompetensi dan Sistem Pengujian di Makassar, 3-5 Juni 2002.

30. Sudarwan Danim, Visi Baru Manajemen Sekolah: Dari Unit Birokrasi ke Lembaga Sekolah, h. 29-30.

31. Dede Rosyada, Paradigma Pendidikan Demokrasi: Sebuah Model Pelibatan Masyarakat Dalam Penyelenggaraan Pendidikan, h. 253.

32. Sudarwan Danim, Visi Baru Manajemen Sekolah: Dari Unit Birokrasi ke Lembaga Sekolah, h. 35.

\section{DAFTAR PUSTAKA:}

Abdullah, Ambo Enre, Pendidikan di Era Otonomi Daerah: Gagasan dan Pengalaman, cet. I, Yogyakarta: Pustaka Timur, 2005.

Arismunandar, Manajemen Pendidikan: Peluang dan Tantangan, cet. II, Makassar: Badan Penerbit Universitas Negeri Makassar, 2006.

Danim, Sudarwan, Visi Baru Manajemen Sekolah: Dari Unit Birokrasi ke Lembaga Sekolah, cet. III, Jakarta: Bumi Aksara, 2008.

Departemen Pendidikan Nasional, Manajemen Peningkatan Mutu Berbasis Sekolah, Buku 1, Jakarta: Direktorat SLTP Ditjen Dikdasmen, 2001.

Kebijakan dan Program Direktorat Sekolah Menengah Umum, Bahan Sosialisasi Kurikulum Berbasis Kompetensi dan Sistem Pengujian di Makassar, 3-5 Juni 2002. 
Gitlow, Howard S., Alan J. Oppenheim, Rosa Oppenheim \& David M. Levine, Quality Management, Third Edition, New York: McGraw Hill, 2005.

Goetsch, David L. \& Stanley B. Davis, Quality Management for Organizational Excellence: Introduction to Total Quality, New Jersey, Pearson Education, 2006.

Ismail, Feiby, Manajemen Berbasis Sekolah: Solusi Peningkatan Kualitas Pendidikan, www.bpkpenabur.or.id

Johnson, James H., 'Total Quality Management In Education", Journal Of Oregon School Study Council, Eugene, v36 n6 Feb. 1993.

Msurgatroyd, Stephen dan Colin Morgan, Total Quality Management and The School, Celtic Court 22 Ballmoor Buckingham: Open University Press, 1994.

Mulyasa, Menjadi Kepala Sekolah Profesional dalam Menyukseskan MBS dan KBK, Bandung: PT. Remaja Rosdakarya, 2005.

Nasution, M.N., Manajemen Mutu Terpadu, Ed: II, Bogor : Ghalia Indonesia, 2005.

Rosyada, Dede, Paradigma Pendidikan Demokrasi: Sebuah Model Pelibatan Masyarakat Dalam Penyelenggaraan Pendidikan, cet. III, Jakarta: Kencana Prenada Media Group, 2007.

Sallis, Edward, Total Quality Management in Education, diterjemahkan oleh Ahmad Ali Riyadi dan Fahrurrozi dengan judul: Manajemen Mutu Pendidikan, cet. VII, Yogyakarta: IRCiSoD, 2008.

Slamet P., Manajemen Berbasis Sekolah. www.pdk.go.id, 2003.

Tilaar, H.A.R., Manajemen Pendidikan Nasional, cet. VI, Bandung: Remaja Rosdakarya, 2003.

www.ssep.net/director.html 